\title{
Russian-Central Asian Relations in the Works of Modern French Researchers
}

\author{
Rafael A. Arslanov, Elizaveta D. Trifonova \\ RUDN University; 6 Miklukho-Maklaya St., Moscow, 117198, Russia; arslanov-ra@rudn.ru
}

\begin{abstract}
The article examines the views of modern French researchers on the relations between Russia and the post-Soviet republics of Central Asia. This allows us to identify various interpretations of Russian foreign policy, and to understand the main approaches of French scholars analyzing the goals and tasks of Russian geostrategy in the region. As the article demonstrates, French historiography, along with the objectivist view on the Central Asian vector in Russian foreign policy, also includes works of ideological nature. Special emphasis is put on French works that focus on Russian political authors who speak of Russia's neo-imperialism. These studies explain the Russian policy in Central Asia through the ruling elite's ambition to resurrect an empire in the post-Soviet space and to return superpower status to Russia. Of special interest is the position of authors who try to explain the Russian attitude to the Central Asian region as, on the one hand, an expression of nostalgic feelings harbored by a great part of the population about the nation's former greatness, assuming that these feelings have an impact on the leadership's policies, and on the other hand, as the Russian leadership's attempt to use Russia's active return to the international arena for the consolidation and self-identification of society. It is observed that some French authors speak of a New Great Game. This very popular concept considers the actions of Russia and other powers operating in the region (USA and China) as a continuation of the historical rivalry between the Russian and British empires in the late $19^{\text {th }}$ and early $20^{\text {th }}$ centuries. Russian authors have always been interested in French historiography; this is due to the latter's scientific prestige and objectivity, and in particular its application of methodologies that further develop the tradition of the Annales School. At the same time, the growing French scholarship on the issue of Russia and post-Soviet Central Asian republics has not yet been subject to close and complex consideration, which defines the novelty of the article.
\end{abstract}

Keywords: French historiography, Central Asia, geopolitics, relations, security, interests, imperial model, Great Game, energy resources, soft power

For citation: Arslanov, Rafael A., and Trifonova, Elizaveta D. "Russian-Central Asian Relations in the Works of Modern French Researchers." RUDN Journal of Russian History 19, no. 4 (November 2020): 979-995. https://doi.org/10.22363/2312-8674-2020-19-4-979-995

\section{Отношения России и стран Центральной Азии в работах современных французских исследователей}

\author{
Р.А. Арсланов, Е.Д. Трифонова \\ Российский университет дружбы народов; 117198, Россия, Москва, \\ ул. Миклухо-Маклая, 6; arslanov-ra@rudn.ru
}

Аннотация: В статье выявляются и анализируются взгляды современных французских исследователей на отношения России и постсоветских республик Центральной Азии. Изучение работ французских ученых дает возможность установить различные трактовки внешней политики России, определить основные подходы к освещению целей и задач ее геостратегии в регионе. В статье отмечается, что наряду с объективистским взглядом на центральноазиатский вектор внешней политики России во французской историографии существует и его идеологизированная

(C) Arslanov R.A., Trifonova E.D., 2020

(c) (i) This work is licensed under a Creative Commons Attribution 4.0 International License

https://creativecommons.org/licenses/by/4.0/ 
интерпретация. В ее рамках политика России в Центральной Азии зачастую объясняется стремлением правящей верхушки возродить на постсоветском пространстве империю, вернуть стране статус сверхдержавы. Интерес вызывает позиция тех авторов, которые пытаются в отношениях России к центральноазиатскому региону найти, с одной стороны, проявление ностальгических чувств значительной части населения о былом величии, их влияние на политику верхов, а с другой, - попытку руководства использовать активное возвращение России на международную арену как средство консолидации и самоидентификации общества. Отмечается, что в работах некоторых французских авторов используется популярная сегодня теория «Новой большой игры», в рамках которой действия России и ведущих государств мира в регионе (США и Китая) рассматриваются как продолжение исторического соперничества российской и британской империй эпохи 2-й половины XIX - начала XX в. Французская историография, благодаря заслуженному научному престижу и, прежде всего, объективности, использованию современных методов, продолжающих традиции школы «Анналов», пользуется вниманием отечественных авторов. Вместе с тем работы французских исследователей, все чаще обращающихся к проблеме отношений России и постсоветских республик Центральной Азии, еще не получили специального и комплексного рассмотрения, что определяет новизну данной статьи.

Ключевые слова: французская историография, Центральная Азия, геополитика, отношения, безопасность, интересы, имперская модель, Большая игра, энергоресурсы, «мягкая сила»

Для цитирования: Арсланов Р.А., Трифонова Е.Д. Отношения России и стран Центральной Азии в работах современных французских исследователей // Вестник Российского университета дружбы народов. Серия: История России. 2020. Т. 19. № 4. С. 979-995. https://doi.org/10.22363/ 2312-8674-2020-19-4-979-995

\section{Introduction}

The views of modern French scholars about the relations between Russia and the postSoviet republics of Central Asia can tell us a great deal. First and foremost, they shed some light on how the western public today sees Moscow's foreign policy in general, as well as its dealings with its former "Asian colonies" in particular. Second, studying French scholarship on the question can help us compare its analysis to Russia's own views about restoring its former empire, a matter that has become particularly relevant in the wake of the events in Crimea in 2014. At the same time, it also provides a new perspective both on the region itself after the Soviet Union's collapse as well as on how Russia has reacted to the new situation.

Meanwhile, such a study provides valuable insights into recent developments in the disciplines of history and political science in France, as well as how the French currently understand modern Russian history and the country's foreign policy. And, by the same token, understanding foreign academic approaches promotes a more globalized, comprehensive and objective analysis.

Of course, Russian scholars have examined how their own compatriots have studied the history of their country's relations with Central Asia, ${ }^{1}$ not to mention the current state of Moscow's ties with the region. ${ }^{2}$ Yet they are also interested in the French literature, even if

${ }^{1}$ S.N. Brezhneva, Istoriografiia prpbelemy prisoyedineniya Turkerstanskogo kraia $k$ Rossii - vtoraia polovina XIX v. - nachalo XXI (Moscow: Moscow University Publ., 2005); S.N. Brezhneva, "Reflection of the idea of acculturation in the resettlement policy of the Russian Empire in Turkestan at the turn of the $19^{\text {th }}-20^{\text {th }}$ centuries," RUDN Journal of Russian History 17, no. 3 (2017): 608-638; B.N. Mironov, Upravlenie etnicheskim mnogoobraziem Rossiiskoi imperii (St. Petersburg: Dmitry Bulanin Publ., 2017); S.N. Abashin, Tsentral'naia Aziia v sostave Rossiiskoi imperii (Moscow: Novoye literaturnoye obozreniye Publ., 2008); R.A. Arslanov, A.L. Klimashin, "Periodicals in Russia at the turn of the $19^{\text {th }}-20^{\text {th }}$ centuries on Russian migrants' sociocultural adaptation in Central Asia," RUDN Journal of Russian History, no. 3 (2017): 347-363.

2 V.V. Naumkin, Interesy Rossii v Tsentral'noi Azii: soderzanie, perspektivy, ogranichiteli (Moscow: RAN Publ., 2013); A.A. Kazantsev, «Bol'shaya igra»s neizvestnymi pravilami: mirovaya politika i Tsentral'naya Aziya (Moscow: MGIMO-Universitet Publ, 2008); S.G. Luzianin, Vostochnaia politika Vladimira Putina. Vozvrashchenie Rossii na "Bol'shoi Vostok" (2004-2008) (Moscow: AST Publ., 2007); K.E. Meshcheriakov, Evoliutsiia vneshnei politiki Rossiiskoi Federatsii v Tsentral'noi Azii (St. Petersburg: SPbSU Publ., 2014); 
they are primarily focused on works about Russia's past, ${ }^{3}$ and the relevant methodology. ${ }^{4}$ Nevertheless, the views of French authors about modern Russia are not neglected. ${ }^{5}$

K.E. Meshcheriakov's work on the historiography of Russo-Central Asian relations, including its French component, is particularly comprehensive. Noting a sharp increase in the number of publications devoted to the Central Asian region after September 11, 2001, he stressed "their internationalization, ... a considerable increase in the quality of the works and the reliability of the conclusions drawn by the authors." At the same time, the existing historiography struck him as ambiguous and inconsistent. Along with the academic studies he analyzed, there were journalistic works which, in his opinion, were ideologically biased. ${ }^{7}$ To a certain extent, the publications of French authors adhered to this general pattern.

There is no study that specifically examines the French interpretation of relations between Russia and the countries of Central Asia. The main reason is that French scholars only began to study this topic relatively recently, i.e. when the region's states gained their independence as the USSR fragmented. However, the possibility of their seceding from the Soviet Union was foreseen. In her book, L'Empire éclaté: La révolte des nations en URSS (The End of an Empire: The Soviet Union in Revolt), the prominent French historian Hélène Carrère d'Encausse predicted the state's collapse. At the same time, she mistakenly attributed the cause to the rising birthrate in the Islamic republics, which, combined with declining standards of living and sharpening internal contradictions, would place tremendous stresses on the Soviet empire. ${ }^{8}$

The historian subsequently revised her conclusion and argued that the reason really lay in the metropole's misguided policy. In her opinion, in the 1970s on the pretext of fighting corruption, Leonid Brezhnev's team began to carry out "serious purges" in the Central Asian republics, which "the nations saw as an attack on their integrity and rights." During the subsequent perestroika era, the "Cotton Case," a campaign against corruption primarily in Uzbekistan,

stirred up memories of this practice and caused widespread discontent, and sometimes led to protests ... that all questioned Soviet feudalism, and ultimately, the whole system. ${ }^{9}$

Another historian, R. Yakemtchouk, had a different view. He questioned the notion that Mikhail Gorbachev's actions had had a major impact on the political behavior of the leaders of Central Asia and drove them to separatism. As he saw it, advocating independence on the one hand, and maintaining economic ties with Russia on the other,

Yu.N. Savichev, Otnosheniia Rossii s tsentral'noaziatskimi stranami SNG v gumanitarnoi sfere (1991-2015) (Moscow: MSU Publ., 2015).

${ }^{3}$ N.G. Kostromina, Teoriia i praktika totalitarizma $v$ otsenke frantsuzskoi istoricheskoi i politicheskoi mysli v XX v. (Kemerovo: Kemerovo State University Publ., 2012); K.A. Tsykova, Rossiia vtoroi poloviny $X I X$ - nachala XX v. v trudakh Anatolia Lerua-Bol'e (Moscow: MSU Publ., 1991); D.A. Iatskova, Vlast' $i$ obshchestvennoe dvizhenie Rossii XIX vo frantsuzskoi istoriografii (Moscow: MSU Publ., 2013).

4 Yu.L. Bessmertnyi, "Kak zhe pisat' istoriiu? Metodolicheskie veianiia vo frantsuzskoi istoriografii 1994-1997," Novaia i noveishaia istoriia, no. 5 (1998): 29-42; A.Ya. Gurevich, Istoricheskii sintez i shkola 'Annalov' (Moscow: Indrik Publ., 1993); A.M. Inergin, Global'naia istoriia' Fernana Brodelia: voprosy metodologii (Tomsk: TSU Publ., 1995); "Mezhdunarodnyi sintez: uroki shkoly 'Annalov," Metodologicheskii sintez: proshloe, nastoiashchee, vozmoshnye perspektivy (Tomk: TSU Publ., 2002): 156; N.V. Trubnikova, Istoricheskoe dviznenie 'Annalov (Tomsk: TSU Publ., 2007).

5 A.V. Gordon, "Russia in the history of French thought (XVII-XXI centuries)," Russia and the modern world, no. 4 (2013): 76-102; N.Iu. Lapina, "Double mirror reflection, or how modern Russia is perceived in France," Russia and the modern world, no. 4 (2013): 58-75; V.P. Chudnov, "Frantsuzskaia istoriografiia raspada SSSR i stanovleniia novoi Rossii," in Rossiia v mirovom politicheskom protsesse: materialy mezhdunarodnoi nauchnoiteoreticheskoi konferentsii (Moscow: RUDN Publ., 1997), 145-149; R.A. Arslanov, T.S. Tolstova, “Outside viewpoint: French researchers about modern Russia.” RUDN Journal of Russian History, no. 3 (2014): 155-162.

${ }^{6}$ Meshcheriakov, "Evoliutsiia vneshnei politiki," 206.

${ }^{7}$ Ibid., 204-205.

${ }^{8}$ H. Carrère d'Encausse, Yevraziyskaya imperiya (Moscow: ROSSPEN Publ., 2007), 283.

${ }^{9}$ Ibid. 
they "... played only an negligible role in the collapse of the USSR." 10 Despite all its inconsistency, Yakemtchouk's conclusion seems closer to the mark, especially since they were severely dismayed by the unilateral decision of the leaders of the three Slavic republics unilaterally to dissolve the unified state at Belovezh at the end of 1991.

This article analyses the French historiography of the Russian Federation's Central Asian policy, to identify the stages of its development, features and trends. The source base consists of general works and special articles by French authors addressing the geopolitical problems of the region, as well as its political, economic and cultural ties with Russia. To help understand this foreign point of view, the author also relied on Russian scholarship.

\section{French views of Russia's policy in Central Asia}

Central Asia is a theme of great interest to Western researchers, including the French. The latter include the aforementioned historians Hélène Carrère d'Encausse and R. Yakemtchouk, a professor of the Louvain Catholic University; the political scientist and orientalist Olivier Roy, the leading researcher at the Foundation for Strategic Research (FRS) Isabelle Facon; the political science professor Thierry Kellner; the international affairs specialist Mohammad-Reza Djalili; the researcher at the National Institute for Oriental Languages and Civilizations (INALCO) David Teurtrie and Professor Anne de Tinguy, who is also affiliated with the Center for International Studies at the Institute for Political Studies (CERISciences Po); Marie Mendras, a political scientist at the National Center for Scientific Research (CNRS) and the Center for International Studies in Political Sciences; and the historian Françoise Thom, who specializes in Russia's regions; among others.

The term "Central Asia" to describe the former Central Asian republics (Kyrgyzstan, Tajikistan, Turkmenistan, Uzbekistan) and Kazakhstan, was established only in the early 1990s. According to the French researchers, the pre-revolutionary name "Turkestan" was replaced by a new one - the Central Asian Soviet Republics and Kazakhstan - mainly to avoid any imperial associations. ${ }^{11}$ At the same time, Western authors have noted the inconsistency and ambiguity of the expression "Central Asia," which from a political point of view, included only the former Soviet republics, but to geographers also comprised Mongolia, Xinjiang, Tibet, Afghanistan, etc. Today, most scholars agree that the concept of Central Asia covers the five former Soviet republics - Kazakhstan, Kyrgyzstan, Turkmenistan, Tajikistan and Uzbekistan. ${ }^{12}$

Russians and foreigners concur that Central Asia was long under the control of Russia and has not had any independent relations with Western countries since the nineteenth century. Furthermore, during the Soviet era, this region was of no geopolitical interest to the US and Europe. Only after the collapse of the Soviet Union, when a "geopolitical hole" emerged there - and especially after the events of September 11, 2001 - did the region begin to attract their close attention. ${ }^{13}$

The Belovezh Accords that disbanded the USSR also led to the Commonwealth of Independent States (CIS) instead - a confederation of former union republics. Some

${ }^{10}$ R. Yakemtchouk, La politique étrangère de la Russie (Paris: l'Harmattan, 2008), 140

${ }^{11} \mathrm{H}$. Carrère d'Encausse, Réformes et revolutions chez les musulmans de l'Empire russe. Bukhara 1867-1924 (Paris: Armand Colin, 1966), 272.

12 I. Facon, "Les enjeux de sécurité en Asie centrale: la politique de la Russie." AFRI, no. 5 (2004): 653-666; T. Kellner, M.-R. Djalili, Géopolitique de la nouvelle Asie Centrale. De la fin de l'URSS à l'après 11 septembre (Genève: Graduate Institute Publications, 2015); C. Poujol, "L'Asie centrale, bilan: quinze années de discours et de pratiques sur l'intégration dans un espace désintégré." Revue internationale et stratégique, no. 64 (2006): 69-78; A. Sellier, J. Sellier, Atlas des peuples d'Orient, Moyen-Orient, Caucase, Asie Centrale (Paris: La Découverte, 1993); O. Roy, L'Asie centrale contemporaine (Paris: Presses Universitaire de France, 2010); D. Teurtrie, Géopolitique de la Russie. Intégration régionale, enjeux énergétiques, influence culturelle (Paris: l'Harmattan, 2010); Yakemtchouk, La politique étrangère de la Russie.

${ }^{13}$ Kellner, Djalili, Géopolitique de la nouvelle Asie Centrale, 16. 
French scholars believe that this development neglected the interests of the Central Asian republics, which caused bitterness and bewilderment, and, as a result, pushed them to closer ties with Western countries. ${ }^{14}$

In the early 1990s it was the West, rather than the neighboring "near abroad," including the states of Central Asia, that became a priority of Russian foreign policy. Russians attributed this turn to a number of factors. First of all, the "European choice" of the Moscow's new democratic leadership led to the perception of Central Asia as "...a bastion of backwardness and the communist nomenklatura." ${ }^{\prime 5}$ Another cause was Russia's difficult economic situation at the time, which encouraged the young government to move toward a market economy "... to distance itself from the subsidized region." 16 The void that emerged after Central Asia's separation from Russia could not be filled by other international actors, including the US, the European Union, China, Turkey or Iran. Some were attracted by its rich natural resources, while others were interested in the geopolitical position of the region, which, especially after September 11, 2001, suddenly turned an international backwater into a stronghold of the fight against the main global threat - international terrorism. Attempts to limit Moscow's influence combined with growing internal problems in the Central Asian countries forced it to return to the region.

French authors understand the relations between Russia and Central Asia in different ways. According to most, Moscow's primary motive is the desire to strengthen its position and ensure the security of both the region and Russia itself. One advocate of this realist position seems to be Carrère d'Encausse. As she argues, in Central Asia, Russia is trying, above all, to strengthen regional security, which is impossible without addressing such urgent threats as Islamic extremism and terrorism. ${ }^{17}$ It should be noted that Carrère d'Encausse attributed Russia's emancipation from Gorbachev's authoritarianism, not to mention the Soviet empire, to internal developments without any support from abroad. ${ }^{18}$

According to Pradon, the Kremlin believes that most countries in the region cannot deal with the growing threats of terrorism, Islamic extremism, and drug trafficking on their own. These challenges to the region's political and economic situation menace Russia, which

remains the only force capable of exerting military influence and contributing to the stabilization of the situation in Central Asia. ${ }^{19}$

As a result, according to most French analysts, despite foreign interference, economic problems, and political weakness, Russia managed to maintain and even strengthen its position there. ${ }^{20}$ Moreover, Francophone Swiss scholars Djalili and Kellner believe that Russia will continue using all its strength and power to achieve its geopolitical goals. ${ }^{21}$

V. Bernard, L. Fort, M. Gangloff and others endeavor to adopt an objective point of view in identifying what drives Russia's Central Asian policy. In their opinion, economic interests and, above all, the desire to take control of its energy resources, are what motivate Moscow. ${ }^{22}$ Using its potential, it eventually managed to restore its historical po-

${ }^{14}$ A. Verdier, "Les relations russo-centrasiatique. Une nouvelle donnée géopolitique, entre méfiance, velléité et intérêt," Les Cahiers de l'Orient, no. 89 (2008): 30.

${ }^{15}$ Kazantsev, Bol'shaya igra, 127.

${ }^{16}$ Ibid., 128.

${ }^{17}$ Karrer-d'Ankoss, Evraziiskaia imperiia, 318-319.

${ }^{18}$ H. Carrère d'Encausse, "La Russie, ma vie, et mes combats pour la vérite," https://youtu.be/P0OvEAz51uk.

${ }^{19}$ H. Pradon, "Les enjeux de sécurité et de la stabilité en Asie central," AFRI, no. 4 (2003): 169.

${ }^{20}$ Teurtrie, Géopolitique de la Russie. Intégration régionale, enjeux énergétiques, influence culturelle; Kellner, Djalili, Géopolitique de la nouvelle Asie Centrale; Yakemtchouk, La politique étrangère de la Russie.

${ }^{21}$ M.-R. Djalili, T. Kellner, "La Russie et la 'nouvelle' Asie centrale", Géostrategiques, no. 1 (2001): 12.

${ }^{22}$ V. Bernard, P. Cvijic, L. Fort, M. Gangloff, R. Moreau, "Russie: Quelle stratégie de puissance?," Base de Connaissance de AEGE, no. 12 (2006): 28. 
sition in maintaining and even increasing its influence there. ${ }^{23}$ According to some, such as Marlène Laruelle (now based in Washington, DC) Russian rapprochement with the region's governments is influenced by migration of the latter's citizens, the development of which is particularly important to Uzbekistan and Tajikistan. ${ }^{24}$

Not all the French are free of bias. Their leadership is often accused intellectual inertia, which manifests itself in the revival of Cold War stereotypes. Thus, according to I. Facon, Russia continues to regard the US and NATO, rather than terrorism, Islamic extremism, organized crime, and drug trafficking as its major adversaries. ${ }^{25}$

Such generalizations, not based on fact, often distort the real picture. Since the late 1990s, Moscow has considered it necessary to unite the international community in its fight against current threats, but the West largely ignores it. Furthermore, Washington pursues the policy of ousting Russia from the spheres of its vital interests, under the auspices of which the process of NATO expansion is ongoing. This strategy includes enlarging NATO as well as efforts draw closer to the countries of Central Asia. And, somewhat contradicting herself, Facon suggests that Moscow use Central Asia for joint actions to combat terrorism. ${ }^{26}$

One French political scientist, F.-G. Dreyfus, had a more original explanation for Russia's attraction to Central Asia. As he put it, when analyzing Russia's policy

...one cannot ignore the sentimental aspect, since at first the Russian Empire and then the Soviet Union invested a great deal effort in developing and supporting Central Asia. Moscow's pride for its sacrifices generates nostalgia. ${ }^{27}$

These sentimental memories of the "great past," according to the author's logic, influence Russia's attitude today to the former Soviet republics. A number of scholars argue that Russians, nostalgic for the USSR Russia, see themselves as "the heir to the colonial past of the empire." ${ }^{28}$ Guided by historical memory, they seek to restore its dominance of Central Asia, thereby confirming their country's status as a great power. ${ }^{29}$

This interpretation resembles the "new imperial turn" in current Anglo-American Russian studies. ${ }^{30}$ According to this approach, Russia sees itself as the rightful heir to both the prerevolutionary empire and the Soviet Union. This continuity manifests itself in the metropole's relations with its former periphery, especially the independent Central Asian republics. On the other hand, Russian attitudes to the region, based on nostalgic memories of past unity, promote such imperial self-identification, to replace the ideological bonds of the Soviet era.

General H. Paris writes more directly about Russia's imperial intentions in Central Asia. In his opinion, Moscow's efforts to restore its former standing within the borders of the former empire and the Soviet Union are driven by its geopolitical interests. ${ }^{31}$ Meanwhile, Russian analysts attribute their country's renewed interest in Central Asia to such factors as geopolitics, rivalry with the US, domestic politics, as well as public opinion.

${ }^{23}$ V. Bernard, P. Cvijic, L. Fort, M. Gangloff, R. Moreau, "Russie: Quelle stratégie de puissance?," Base de Connaissance de AEGE, no. 12 (2006): 3; C. Reveillard, "La stratégie de la renaissance. Retour sur certaines évolutions de la situation géostratégique Russe," Géostratégiques. no. 24 (2016): 76.

${ }^{24}$ M. Laruelle, "Le nouveaux role de la Russie en Asie Centrale: les migrations de travail des Centreasiatiques vers la Fédération russe," Revue internationale et stratégique, no. 4 (2006): 133.

${ }^{25}$ Facon, Les enjeux de sécurité, 653-666.

${ }^{26}$ Ibid., 653-655; H. Carrère d'Encausse, La Russie entre deux mondes (Paris: Fayard, 2010), 116.

${ }^{27}$ F.-G. Dreyfus, "La Russie et l'Asie centrale," Géostratégiques, no. 12 (2006): 99-106.

${ }^{28}$ A. Leklerk, Russkoye vliyaniye v Yevrazii. Geopoliticheskaya istoriya ot stanovleniya gosudarstva do vremen Putina (Moscow: Al'pina Pablisher Publ., 2014); P. Dombrowski, "La diplomatie de la Russie envers son voisinage," Histoire \& Liberté, no. 30 (2007): 53.

29 Th. Gomart, "Quelle influence russe dans l'espace post-soviétique?" Le courier des pays de l'Est, no. 1006 (2006): 6; Roy, L'Asie centrale contemporaine, 77.

${ }^{30}$ V.V. Ageeva, "Exploring Russia as an Empire: Innovations in Anglo-American Historical Russian Studies in the 1990s-2010s," Theory and practice of social development, no. 2 (2015): 70-72.

${ }^{31}$ H. Paris, "La politique russe en Asie centrale," Géostrategiques, no. 28 (2010): 43-52. 
Thus, according to the prominent orientalist A. A. Kazantsev, the failure of the liberal reforms and the perception of the USSR's dissolution as a catastrophe by many voters forced Boris Yeltsin to "position himself as a supporter of the restoration of the union republics' unity" in his campaign for the 1996 presidential elections. ${ }^{32}$

A look at the different views on the Russian presence in Central Asia suggests that, despite its diversity, French scholarship is dominated by realists, in other words, those who believe that Moscow is driven primarily by the need to protect its borders and maintain stability in the region. This is not necessarily the approach of the Anglo-American literature. For example, Stephen Blank, a Senior Fellow at the Foreign Policy Research Institute in Philadelphia, argues that

the dominance of Russia and China in the region is based solely on their willingness to support the local authoritarian regimes. The more repressive policies the local authorities pursue, the more dissatisfaction this causes among the population of the respective republics, which forces their leadership to constantly increase the degree of their interaction with Moscow and Beijing. ${ }^{33}$

According to the Russian orientalist K.E. Meshcheriakov, Blank ignores the "peculiarities of the political culture of the region's countries," which leads him to erroneous conclusions about "the nature of their political system and the reasons for their interest in developing the dialogue with Russia and China..." ${ }^{34}$ The American scholar's judgements reflect a revival of the ideological interpretation of Russia's foreign policy in the region.

\section{Stages, forms and results of cooperation}

How did the French see developments in the relations between the Russian Federation and Central Asia's newly independent republics? Having detected Moscow's waning interest in the region after 1991, they reported an upsurge when Yeltsin appointed Evgenii Primakov to be his foreign minister in 1996, and, four years later, when Putin's Foreign Policy Concept declared Central Asia to be a priority, concluded it would be lasting. ${ }^{35}$ French analysts tend to link changes in Russian diplomacy to the country's leader. Thus, they ascribed the decline to Yeltsin and its revival to his successor.

French scholars believe that Russia's policy in Central Asia went through a series of stages, which were determined both by domestic factors and various changes in the region's countries. At the same time, they pointed to their leaders' somewhat contradictory endeavors to benefit from their historic links with Moscow without being overly captive to its influence, on the one hand, without retreating to isolationism on the other - and avoid the tragic fate of Tajikistan in the 1990s. ${ }^{36}$

One effort to remedy the situation was their effort to establish the Commonwealth of Independent States (CIS). According to Yakemtchouk, the new institution was meant to mitigate the potential dangers of the Soviet Union's disintegration. ${ }^{37}$ At the same time, the Central Asian republics, with the possible exception of Turkmenistan, hoped it would guarantee their integration. Thus, a number of French authors noted the enthusiasm of Kyrgyzstan, Tajikistan, and, in particular, Kazakhstan, to promote the CIS. ${ }^{38}$

\footnotetext{
32 Kazantsev, "Bol'shaia igra," 132.

${ }^{33}$ Meshcheriakov, "Evoliutsiia vneshnei politiki," 152.

34 Ibid.
}

${ }^{35}$ I. Facon, "Les enjeux de sécurité en Asie centrale: la politique de la Russie," 653; Djalili, Kellner, "La Russie et la 'nouvelle' Asie centrale," 58; Kontseptiia vneshnei politiki Rossiiskoi Federatsii (23 June 2000), https://dokipedia.ru/document/5187119.

${ }^{36}$ Kellner, Djalili, Géopolitique de la nouvelle Asie Centrale, 63.

${ }^{37}$ Yakemtchouk, La politique étrangère de la Russie, 54.

${ }^{38}$ Carrère d'Encausse, La Russie entre; Kellner T., Djalili M. Géopolitique de la nouvelle Asie Centrale; A. de Tinguy, "La sortie de l'Empire: le poids de l'héritage," Questions internationales, no. 27 (2007); Yakemtchouk, La politique étrangère de la Russie. 
Yet some of them discount the effectiveness of the CIS, since the organization continues to exist only due to large flows of migration between its members. ${ }^{39}$ Most Central Asian economies rely on remittances by immigrants who live and work in Russia. According to political analyst M. Mendras, their secession from the CIS would mean the introduction of a visa regime with Russia and the forced return of migrant workers to their homeland, with the attendant social and economic disruption. ${ }^{40}$ By the same token, Moscow also has an important stake in the matter, since it has been stepping up its efforts to put the process on a solid legal footing.

Uzbekistan's role in the CIS is of particular interest, since in 1999 it temporarily joined GUAM (the Organization for Democracy and Economic Development), a grouping that opposes Russia's influence in the post-Soviet space. ${ }^{41}$ Some authors consider this event as the beginning of the end of Russia's influence in Central Asia, not to mention the collapse of the CIS. ${ }^{42}$ However, this interpretation seems off base, and in any case Islam Karimov withdrew Uzbekistan's membership six years later.

The events of September 11, 2001, as well as the region's concurrent color revolutions, had a major impact on Russo-Central Asian relations. Among other, these developments led to accusations in the West of rising authoritarianism and violations of human rights by Central Asian governments, which, French analysts argued, accelerated their turn towards both Moscow and Beijing at the expense of Western influence. ${ }^{43}$ As a result, the West itself forced the countries of Central Asia to act in the direction necessary for Russia. ${ }^{44}$

However, a number of them believe that after 9/11, the West's involvement in the region actually increased, as American military bases operated in Uzbekistan until 2005 and in Kyrgyzstan to $2009 .^{45}$ They concluded that the main result was that the Central Asian states began to turn their backs on Russia. Furthermore, the US military presence was accompanied by significant financial support, which, in turn, led to a confrontation of China and Russia with the Americans. ${ }^{46}$ However, this view may have overestimated the appeal of the West, as well as ignoring China's role. Historian H. Carrère d'Encausse may well have been closer to the mark when she argued that,

relying on the growing instability and referring to the principle of collective security, Russia managed to gain military advantages in the region by deploying its bases there. By acting as a defender of those states which were temporarily tempted to play the American game like Ukraine and Georgia, Moscow actually managed to improve their relations. ${ }^{47}$

French analysts have considered the impact of regional organizations in advancing Central Asian integration. They paid particular attention to the Collective Security Treaty Organization (CSTO), established under the auspices of the CIS in 2002 on the basis of the Collective Security Treaty, signed on May 15, 1992 in Tashkent by Kazakhstan, Kyrgyzstan, Tajikistan and Uzbekistan. ${ }^{48}$ However, as already noted, Uzbekistan refused to extend this agreement in 1999. Although it rejoined in 2006, it did so within the framework of the CSTO. Some consider the CSTO to be a "NATO of the Near Abroad," the only

\footnotetext{
39 Teurtrie, "Géopolitique de la Russie," 22.

${ }^{40}$ M. Mendras, "La Russie en mal de politique étrangère," Pouvoirs, no. 88 (1999): 111.

${ }^{41}$ Teurtrie. "Géopolitique de la Russie," 93; Carrère d'Encausse, La Russie entre, 149.

42 Verdier, "Les relations russo-centrasiatique," 36.

${ }^{43}$ S. Peyrouse, "Quinze ans après l'indépendance, quels nouveaux enjeux en Asie Centrale?" Revue internationale et stratégique 64, no. 4 (2006): 66; Yakemtchouk, La politique étrangère de la Russie, 144.

44 Teurtrie, "Géopolitique de la Russie," 101.

${ }^{45}$ Kellner, Djalili, Géopolitique de la nouvelle Asie Centrale, 51.

${ }^{46}$ Facon, Les enjeux de sécurité, 661.

${ }^{47}$ Carrère d'Encausse, La Russie entre, 118-119.

${ }^{48}$ I. Facon, "L'organisation de coopération de Shanghai. Ambitions et intérêts russes," Le courrier des pays de l'Est 1055, no. 3 (2006): 32; "Dogovor o kollektivnoy bezopasnosti ot 15 maya 1992 g.," https://odkbcsto.org/documents/documents/dogovor_o_kollektivnoy_bezopasnosti/.
} 
security alliance that included not only Central Asian governments, but also former Soviet republics in Europe and the Caucasus. ${ }^{49}$

To counter Western influence in the region, Russia turned to China. In 2001, the Shanghai Forum was transformed into the Shanghai Cooperation Organization (SCO), one of whose goals, according to French historian Françoise Thom, became "curbing the influence of Western countries in Central Asia." ${ }^{50}$ Initially meant to promote the region's economic development, the SCO set more ambitious goals, including combating terrorism, US dominance, cooperation in drug trafficking control, etc. Some researchers believe that the SCO, which is the most effective regional body, ${ }^{51}$ is becoming an instrument for Russia, which is using it to try to draw the former Soviet Central Asian republics closer to itself, as well counterbalance American influence in the region - not to mention the latter's global hegemony. ${ }^{52}$ At the same time, others believe that Moscow relies on the SCO, above all, to counter the economic ambitions of Beijing, as it tries to set up a free trade zone within the organization. ${ }^{53}$

Since 2003, the SCO has been one of the instruments for Russia and China to try to limit the political influence of Western countries in Central Asia. ${ }^{54}$ According to a number of scholars, in this context, the events in Andijan in May 2005 became an opportunity for Russia to advance its interests there with the help of the SCO. ${ }^{55}$ By supporting Tashkent, which portrayed the city's revolt as terrorism and extremism, Russia, along with the SCO, opposed West's call for an international investigation and its accusation of "indiscriminate use of force" in suppressing the uprising. ${ }^{56}$ As a result, Tashkent renounced the presence of NATO military bases on its territory, which led to its rapprochement with Moscow. ${ }^{57}$

A number of French authors see the confrontation between the West and Russia in Central Asia as a renewal of the Great Game - the struggle of Russia and Great Britain for influence in the region a century earlier. Modern journalists increasingly used the term "New Great Game," replacing the Americans for the British. At the same time, according to Colonel Vincent de Kytspotter, after 9/11, the interests of the players coincided, and "Russia became the first country to support the US in its war on terrorism." He noted, with some surprise, a new development - ".. cooperation along with rivalry." 58 However, at the end of 2003, Moscow and Beijing grew dissatisfied with Washington's "prolonged military presence" in the region, which they saw as "undisguised expansion, ....a strategic threat to the interests of their national security." And in the Central Asian states "...suspicion of the true motives of the American invasion grew." 59 As a result, the French colonel correctly predicted the imminent withdrawal of the US troops from Central Asia and the change in the balance of forces in favor of Russia and China.

French authors also consider increasing Sino-Russian cooperation in the region as another aspect of the New Great Game. According to Isabelle Facon, the two states act together quite closely in the geopolitical sphere to confront other external players. At the same time,

49 Teurtrie, “Géopolitique de la Russie,” 89-90; Carrère d'Encausse, La Russie entre, 112.

${ }^{50}$ Fr. Thom, "Une politique étrangère déterminée par les dynamiques internes," Boulevard Exterieur (2012), https://www.boulevard-exterieur.com/Une-politique-etrangere-determinee-par-les-dynamiques-internes.html.

${ }^{51}$ C. Poujol, "L'Asie centrale, bilan: quinze années de discours et de pratiques sur l'intégration dans un espace désintégré", Revue internationale et stratégique, no. 64 (2006): 70; Facon "L'organisation de coopération de Shanghai", 30-31.

52 Yakemtchouk, La politique étrangère de la Russie, 142.

53 H. Rousselot, "Le club de l'énergie de l'OSC. Un élément (moteur) d'intégration régionale?" Relations internationales. no 145 (2011): 121.

${ }^{54}$ Facon, "L'organisation de coopération de Shanghai”, 31.

${ }^{55}$ Kellner, Djalili, Géopolitique de la nouvelle Asie Centrale, 80; Carrère d'Encausse, La Russie entre, 117-119.

${ }^{56}$ Carrère d'Encausse, La Russie entre, 119-120.

${ }^{57}$ Ibid.; Verdier, "Les relations russo-centrasiatique," 38.

${ }^{58}$ V. de Kitspotter, "Bol'shaia igra v tsentrel'noi azii," Iadernyi kontrol', no. 1 (2005): 91.

${ }^{59}$ Ibid., 93. 
they also compete economically, which, according Facon, leads to Russia's mistrust. ${ }^{60}$ Yet, others believe that, while it is growing, Beijing's influence in the regions is still less than that of Moscow. ${ }^{61}$ Sebastien Peyrouse's suggestion ${ }^{62}$ that the Chinese may well eclipse the Russians there underestimates their reliance on the latter as the only guarantors of its security.

Most French authors believe that Vladimir Putin has managed to strengthen Russia's position in Central Asia. He reassures the leaders of its republics who fear the manifestation about Moscow's imperial ambitions by arguing that its previous dominance is not an obstacle to better relations, and even enhances them. By stressing Central Asia's security and stability as well as warning about the West's attempts to intervene in its affairs, the Kremlin, in the opinion of a number of French analysis, has brought about its rapprochement with its republics. ${ }^{63}$

At the same time, they believe that both the Central Asian states and Russia prefer to cooperate not on a bilateral but on a regional basis. To do this, they use various organizations that, on the one hand, according to some authors, protect the region's countries from Russia's neo-imperial ambitions, and on the other hand, make it easier for the latter to control the post-Soviet space and create the conditions for Central Asian integration. ${ }^{64}$ Most of them argue that, while the SCO is one of the most important regional organizations, the CIS in ineffective as a tool for consolidating Moscow's hold on the region, or even a "failure". ${ }^{65}$ Such institutions as the CSTO or the Customs Union, later transformed into the EurAsEC, while promoting Russian influence, do not include all of Central Asia's governments.

\section{Economic cooperation}

The French also pay attention to Russian economic cooperation with Central Asia. First and foremost, they discuss the role of various relevant organizations. Thus, in 1995, Kazakhstan, Russia and Belarus established the Customs Union, which Kyrgyzstan and Tajikistan joined in 1996 and in 1998, respectively, and was transformed into the Eurasian Economic Community (EurAsEC) in 2000. The organization's purpose is to establish a common market and coordinate other economic activities. According to most of them, the Customs Union and the EurAsEC are the main priorities of Vladimir Putin's diplomacy in Central Asia, which is aimed at promoting integration. ${ }^{66}$ However, some are highly skeptical of their effectiveness, and emphasize that Russia uses these economic associations primarily for political purposes to maintain its influence and counter such rivals as the EU and China in Central Asia. ${ }^{67}$ At the same time, Russia had to make concessions, allowing the citizens of its partners to move freely within the the union, thereby increasing their presence in Russia. In addition, it also began to export hydrocarbons to its EurAsEC partners at a lower price. ${ }^{68}$

The French conclude that Russia is less interested in economic cooperation with Central Asia than its republics themselves, with the probable exception of Kazakhstan. ${ }^{69}$ As some suggest, despite all the fluctuations and difficulties, Russia remains the key part-

${ }^{60}$ I. Facon, “Asie centrale comme enjeux dans le 'partenariat strategique' sino-russe," Recherches \& Documents, no. 6 (2008): 35.

${ }^{61}$ R. Cagnat, “Asie centrale, jouet des grandes puissances: le très grand jeu," Les notes de l' IRIS, no. 3 (2010): 12.

${ }^{62}$ S. Peyrouse, "La présence chinoise en Asie central: Portée géopolitique, engeux économique et impact culturelle," Les Etudes de CERI, no. 48 (2008): 33.

${ }^{63}$ Leklerk, Russkoye vliyaniye v Yevrazii, 291-292; S. Peyrouse, "Quinze ans après l'indépendance, quels nouveaux enjeux en Asie Centrale?" Revue internationale et stratégique, no. 64 (2006): 66; Yakemtchouk, La politique étrangère de la Russie, 144.

${ }^{64}$ Facon, Les enjeux de sécurité; Teurtrie D. "La langue russe"; Carrère d'Encausse, La Russie entre, 112.

${ }^{65}$ Kellner, Djalili, Géopolitique de la nouvelle Asie Centrale, 64.

${ }^{66}$ Leklerk, Russkoye vliyaniye v Yevrazii, 295-296; Facon, Les enjeux de sécurité; Kellner, Djalili, Géopolitique de la nouvelle Asie Centrale, 58.

${ }^{67}$ Teurtrie, "Géopolitique de la Russie," 69; Verdier, "Les relations russo-centrasiatique," 41-42.

68 Ibid., 64.

${ }^{69}$ Kellner, Djalili, Géopolitique de la nouvelle Asie Centrale, 59. 
ner of the Central Asian states in the economic sphere. ${ }^{70}$ While acknowledging the increasing importance of China in the region's economy, Russians tend to agree. ${ }^{71}$

Energy occupies a prominent place in French studies of the region, especially Russian policy in this regard. Thus, according to A. Leclerc, energy is "an effective tool that Russia uses to occupy the dominant position in the Central Asian region." time, some conclude that Russia uses energy as a tool to advance its interests not only in Central Asia, but throughout the post-Soviet space. Thom believes that "by using the gas pipelines of Central Asia, Russia is trying to restore its hegemony not only in the region, but also in Europe."73 Others emphasize that by "using the transport infrastructures left over from the times of the USSR as a lever of influence, Russia is trying to restore its traditional influence in Central Asia," which it lost during Boris Yeltsin's reign. ${ }^{74}$

Among other, Russia blocked the construction of the oil pipeline through the Caspian Sea, and, to maintain monopoly on the transportation of hydrocarbons in the region, it tried to force Kazakhstan and Turkmenistan to export them through its own territory. ${ }^{75}$ As a result, these countries had to seek new export routes. For example, Turkmenistan began bypassing Russia by selling its gas at a low price to Iran through a small pipeline built at the end of 1997.

Faced with the threat of cutting its ties with its CIS partners, as well as with the possibility that Central Asian states bypass Russia to transport its gas, the Kremlin forced Gazprom to reverse its position and conclude an agreement with Turkmenistan in 1999, to resume the export of the latter's gas to Russia for export to Ukraine. D. Teurtrie considers that the 17 December 1999 agreement with Turkmenistan was extremely beneficial for Russia, since it not only allows "maintaining control over the export routes of Turkmenistan gas, but also questions the usefulness of the Trans-Caspian gas pipeline." ${ }^{, 6}$ As for the Caspian Pipeline Consortium (CPC), an oil transportation project Russia, Kazakhstan and the leading oil companies created to build and operate the oil pipeline connecting the coast of Kazakhstan with the port of Novorossiysk, to Teurtrie it was Russia's first victory in the struggle for the Caspian Sea, because it allowed the country to dominate oil transit in the region. ${ }^{77}$

At the same time, according to French researchers, the Kremlin realizes that it will not be able to control all Central Asian exports of hydrocarbons. That is why it also relies on collective cooperation on a contractual basis, as long as it precludes the participation of such competitors as the US. ${ }^{78}$ Russia has to

make significant efforts to maintain and strengthen in each case the dependence that binds its partners. ${ }^{79}$

The economic recovery and increased coordination between the Russian government and its energy companies have allowed Moscow somewhat to restore the pattern of its energy and economic policy toward Central Asia. It also uses energy to restore its influence there, for example, by creating EurAsEC to, among other, restore its control over oil and gas exports from Kazakhstan and Turkmenistan. ${ }^{80}$ However, growing competition

70 Yakemtchouk, La politique étrangère de la Russie, 141.

${ }^{71}$ Kazantsev, "Bol'shaia igra," 150, 151.

${ }^{72}$ Leklerk, Russkoye vliyaniye v Yevrazii, 293.

${ }^{73}$ Fr. Thom, "Politique énergétique de la Russie," European Security \& Defence, www.europeansecurity.com/index.php?id=4338

${ }^{74}$ Gomart, "Quelle influence russe dans l'espace post-soviétique?," 8.

75 Thom, "Politique énergétique de la Russie."

76 Teurtrie, Géopolitique de la Russie, 181-182.

77 Ibid., 187.

${ }^{78}$ Ibid., 181-185.

79 Tinguy, "La sortie de l'Empire".

${ }^{80}$ Fr. Thom, "Vladimir Putin's Russia," European Security \& Defence, www.european-security.com/ index.php?id=3004 
is increasingly challenging Russia's role as a key player in the regional energy sector. ${ }^{81}$ In general, the French have concluded that economic issues, including the transportation of hydrocarbons from Central Asia, have become political ones for Russia.

\section{Protection of the Russian population and soft power policy}

French studies examine the situation of the Russian-speaking population living in the region, as well as the Russian Federation's efforts to protect it. Russians have suggested more than once that their language and culture enabled the peoples of Central Asia to join European civilization and become a model for modernization for their Muslim neighbors. ${ }^{82}$ By the same token, the departure of Russians after the collapse of the USSR, especially the region's southern zone, i.e. the demise of the "Russian World," had dire economic and cultural consequences.

The French agree about the negative aspects of the nationalization policy pursued by a number of Central Asian states, which has hastened the exodus of many ethnic Russians. They are particularly concerned that Russian has lost the status of an official language and is no longer taught in school, despite the fact that it remains a necessary element of communication in the post-Soviet space. ${ }^{83}$ On the other hand, they note that, with Vladimir Putin's rise to power, the attitude towards Russian culture and the Russian-speaking population in the region began to change. In many ways, Putin created an environment more favorably disposed towards Russia as well towards Russians living abroad through his deft use of "soft power." 84 Thus, Russian remains important throughout Central Asia, and even remains an official language in Kazakhstan and Kyrgyzstan.

L. Delcour and A. de Tinguy examined "The Russian Language 2006-10" initiative, whose goals included promoting the language's role in the CIS' integration, supporting the study of Russia's language and culture abroad, and meeting the needs of those who speak it outside of Russia. ${ }^{85}$ For example, in the framework of this program, the Commission on the Affairs of Compatriots of the Government of Russia and the Moscow Mayor's Office for 2000-3 sent more than one hundred thousand Russian language textbooks to Tajikistan. This is one example of the Kremlin's cultural diplomacy, which is most pronounced in its relations with Dushanbe. Among other, in 2003 the two governments signed an agreement to build a television transmitting station to broadcast Russian programs.

Other examples of Central Asia's return to the Russian cultural space are the "Days of the Russian Language" in Turkmenistan, the opening of the joint Russian-Turkmen A.S. Pushkin School in Ashkhabad, and teaching the Russian language in Kazakh schools. In addition, the Russians who remained in the Central Asian states after the collapse of the USSR act as ambassadors for their culture there. ${ }^{86}$ According to some authors, the Russian government's migration policy also contributes to the growing influence of its culture in Central Asia. ${ }^{87}$

Marlène Laruelle, suggests that Putin's policy to support his compatriots abroad is a symptom of Russia's recovery from the "complex of a collapsed empire." ${ }^{\prime 8}$ Thus, as she and

\footnotetext{
${ }^{81}$ Carrère d'Encausse, La Russie entre deux mondes, 175.

${ }^{82}$ Kazantsev, "Bol'shaia igra," 122.

${ }^{83}$ L. Delcour, "Un nouvel aplomb sur la scène internationale? Comment la Russie voit-elle le monde?
} Éléments d'analyse d'une politique étrangère en mutation," Revue internationale et stratégique, no. 68 (2003): 139-140; Teurtrie, Géopolitique de la Russie; Yakemtchouk, La politique étrangère de la Russie.

${ }^{84}$ Delcour, Un nouvel aplomb sur la scène internationale, 40.

85 Ibid., 140; Tinguy, "La sortie de l'Empire," 19; "Federal'naia tselevaia programma 'Russkii iazyk (2006-1010 gody)," https://elementy.ru/Library9/p833.htm

${ }^{86}$ Teurtrie, Géopolitique de la Russie, 302.

${ }^{87}$ Ibid., 314.

${ }^{88}$ M. Laruelle, "La question des Russes de proche-étranger en Russie (1991-2006)," Les Etudes de CERI, no. 126 (2006): 41. 
other French analysts suggest, "soft power" helps restore Russia's influence in Central Asia. ${ }^{89}$ And, despite the fact that most of its governments have abandoned Russian as an official language, it still remains the main means of communication in the post-Soviet space.

\section{Conclusion}

French scholars pay particular attention to Russia's relations with Central Asia. They are primarily interested in the Moscow's geopolitical aspirations, as well as the methods and results of achieving these. To a lesser extent, they also examine the economic and cultural ties between Russia and the countries of the region.

The French literature can be divided into three stages. The first, from 1992 to 1995 , was marked by Russia's withdrawal from the region as a result of a number external and internal political factors. The years 1996 to 2001 saw Russia's return and the priority it gave to the Central Asian vector in its foreign policy. By the way, an indirect evidence of this process, as well as the growing international importance of the region, was the growth of Russo-Central Asian relations as a distinct field of scholarship. Meanwhile, since 2003, as the Kremlin's role in the region has strengthened, French authors are beginning to consider it as the dominant force, although they also pay attention to other players there.

French scholarship, which is fundamentally positivist, is difficult to characterize. It is distinguished by a diversity of opinions, even in the works of the same author. There are two main approaches: the objective one, which explains Moscow's policy by its geopolitical interests and, above all, its desire to ensure its own security, and there is the ideological one, which sees it as neo-imperial. The main argument comes down to interpreting the goal of Russia's foreign policy as the desire of its leadership to revive power, regain the status of a superpower, and most importantly, to rally the population's support for its goals. This suggests that the cooperation between Russia and the countries of the region is based on the proximity of their authoritarian regimes, the Kremlin's desire to provide military assistance, as well as to prevent the establishment of democracy and civil liberties that would inevitably sweep aside the rulers and lead to the region's reorientation toward the West. At the same time, it seems that, after the events of the "Crimean Spring" in 2014, the neo-imperial approach has acquired certain relevance.

The neo-imperial paradigm, emphasizing continuity in the development of Russia as empire, Soviet Union, and now, federation is seen as relevant to understand the country's relations with its neighbors, above all, Central Asia. Russian perception of this region as the former part of a whole, cherished and reinvigorated by the center, and nostalgia for the past are catalysts for imperial self-identification to replace the Soviet era's ideological bonds. The ideological approach appears most often in journalism, which frees the author from the norms of scientific evidence and provides an opportunity for subjective conclusions and value judgments.

French scholars have contributed to the study of the relations between modern Russia and the countries of Central Asia. Hélène Carrère d'Encausse has been particularly important. She sees virtue in the fact that Russia destroyed its empire on its own initiative and should be praised for enduring all the consequent negative socio-economic and political consequences.

Most French researchers do not see neo-imperialism as the dominant element of Russian national identity. At the same time, the argument of one scholar is quite characteristic of the ambiguities inherent not only of the French literature, but its political culture as a whole:

The Russian empire ceased to exist, but apparently quitting an empire is not complete: it is a long, painful process ... Russia's leaders face great difficulties in trying to turn the page, to present the post-

89 Tinguy, “La sortie de l'Empire,”19; Teurtrie, Géopolitique de la Russie, 319. 
Soviet space not as their zone of influence, but instead to consider their partners as truly sovereign states free to pursue their own decisions, and to admit that the historical memory of Russia does not necessarily coincide with the memory of its neighbors. ${ }^{90}$

Nevertheless, the prevailing opinion among the French authors is that Russia, by abandoning its historic great-power traditions and ideas of a special mission, is seeking a new path toward mutually beneficial and equal cooperation while also promoting its geopolitical interests in Central Asia.

Рукопись поступила: 26 апреля 2020 г.

Submitted: 26 April 2020.

\section{References}

Abashin, S.N. Tsentral'naia Aziia v sostave Rossiiskoi imperii. Moscow: Novoye literaturnoye obozreniye Publ., 2008 (in Russian).

Ageeva, V.V. "Exploring Russia as an Empire: Innovations in Anglo-American Historical Russian Studies in the 1990s-2010s." Theory and practice of social development, no. 2 (2015): 65-78 (in Russian).

Arslanov, R.A., and Klimashin, A.L. "Periodicals in Russia at the turn of the $19^{\text {th }}-20^{\text {th }}$ centuries on Russian migrants' sociocultural adaptation in Central Asia." RUDN Journal of Russian History, no. 3 (2017): 347-363 (in Russian).

Arslanov, R.A., and Tolstova, T.S. "Outside viewpoint: French researchers about modern Russia." RUDN Journal of Russian History, no. 3 (2014): 155-162 (in Russian).

Bernard, V., Cvijic, P., Fort, L., Gangloff, M., and Moreau, R. "Russie: Quelle stratégie de puissance?" Base de Connaissance de AEGE, no. 12 (2006): 28-35 (in French).

Bessmertnyi, Iu.L. "Kak zhe pisat' istoriiu? Metodolicheskie veianiia vo frantsuzskoi istoriografii 1994-1997." Novaia i noveishaia istoriia, no. 5 (1998): 29-42 (in Russian).

Brezhneva, S.N. "Reflection of the idea of acculturation in the resettlement policy of the Russian Empire in Turkestan at the turn of the $19^{\text {th }}-20^{\text {th }}$ centuries," RUDN Journal of Russian History 17, no. 3 (2017): 608-638 (in Russian).

Brezhneva, S.N. Istoriografiia problemy prisoedineniya Turkerstanskogo kraia $k$ Rossii vtoraia polovina XIX v. - nachalo XXI. Moscow: Moscow University Publ., 2005 (in Russian).

Cagnat, R. "Asie centrale, jouet des grandes puissences: le Très Grand Jeu." Les notes de l' IRIS, no. 5 (2010): 45-53 (in French).

Carrère d'Encausse H. Yevraziyskaya imperiya. Moscow: ROSSPEN Publ., 2007 (in Russian).

Carrère d'Encausse, H. L'Empire éclaté. Paris: Flammarion, 1979 (in Russian).

Carrère d'Encausse, H. La Russie entre deux mondes. Paris: Fayard. 2010 (in French).

Carrère d'Encausse, H. Réformes et revolutions chez les musulmans de l'Empire russe. Bukhara 1867-1924. Paris: Armand Colin, 1966 (in French).

Chudnov, V.P. "Frantsuzskaia istoriografiia raspada SSSR i stanovleniia novoi Rossii," in Rossiia v mirovom politicheskom protsesse: materialy mezhdunarodnoi nauchnoi-teoreticheskoi konferentsii, 145-149. Moscow: RUDN Publ., 1997 (in Russian).

Delcour, L. "Un nouvel aplomb sur la scène internationale? Comment la Russie voit-elle le monde? Éléments d'analyse d'une politique étrangère en mutation." Revue internationale et stratégique, no. 68 (2007): 133-141 (in French).

Djalili M.-R., and Kellner, T. "La Russie et la «nouvelle» Asie central." Géostrategiques, no. 1 (2001): $10-23$ (in French).

Dreyfus, F.-G. "La Russie et l'Asie centrale.” Géostratégiques, no. 12 (2006): 99-106 (in French).

Facon, I. "L'Asie centrale comme enjeu dans le partenariat stratégique sino-russe." Recherches et documents. Courrier des pays de l'Est, no. 6 (2008): 23-32 (in French).

Facon, I. "Les enjeux de sécurité en Asie centrale: la politique de la Russie." AFRI, no. 5 (2004): 653-666 (in French).

Facon, I. "L'organisation de coopération de Shanghai. Ambitions et intérêts russes." Le courrier des pays de l'Est 1055, no. 3 (2006): 26-37 (in French).

Gomart, Th. "Quelle influence russe dans l'espace post-soviétique?" Le courier des pays de l'Est 1055, no. 3 (2006): 4-13 (in French).

90 Tinguy, "La sortie de l'Empire”, 20. 
Gordon, A.V. "Russia in the history of French thought (XVII-XXI centuries)." Russia and the modern world, no. 4 (2013): 76-102 (in Russian).

Gurevich, A.Ia. Istoricheskii sintez i shkola 'Annalov.' Moscow: Indrik Publ., 1993 (in Russian).

Iatskova, D.A. Vlast' $i$ obshchestvennoe dvizhenie Rossii XIX vo frantsuzskoi istoriografii. Moscow: MSU Publ., 2013 (in Russian).

Inergin, A.M. Global'naia istoriia' Fernana Brodelia: voprosu metodologii. Tomsk: TSU Publ., 1995 (in Russian).

Kazantsev, A.A. «Bol'shaya igra» s neizvestnymi pravilami: mirovaya politika i Tsentral'naya Aziya. Moscow: MGIMO-Universitet Publ, 2008 (in Russian).

Kellner, T., and Djalili, M.-R. Géopolitique de la nouvelle Asie Centrale. De la fin de l'URSS à l'après 11 septembre. Genève: Graduate Institute Publications, 2015 (in French).

Kitspotter, V. de. "The Great Game in Central Asia." Nuclear Control, no. 1 (2005): 81-102 (in Russian).

Kostromina, N.G. Teoriia i praktika totalitarizma $v$ otsenke frantsuzskoi istoricheskoi i politicheskoi mysli v XX v. Kemerovo: Kemerovo State University Publ., 2012 (in Russian).

Laruelle, M. "La question des Russes de proche-étranger en Russie (1991-2006)." Les Etudes de CERI, no. 126 (2006): 15-21 (in French).

Laruelle, M. "Le nouveaux role de la Russie en Asie Centrale: les migrations de travail des Centre-asiatiques vers la Fédération russe." Revue internationale et stratégique, no. 4 (2006): 133-142 (in French).

Leklerk, A. Russkoye vliyaniye v Yevrazii. Geopoliticheskaya istoriya ot stanovleniya gosudarstva do vremen Putina. Moscow: Al'pina Pablisher Publ., 2014 (in Russian).

Luzianin, S.G. Vostochnaia politika Vladimira Putina. Vozvrashchenie Rossii na "Bol'shoi Vostok" (2004-2008). Moscow: AST Publ., 2007 (in Russian).

Mendras, M. "La Russie en mal de politique étrangère." Pouvoirs, no. 88 (1999): 107-120 (in French).

Meshcheryakov, K.Ye. Evolyutsiya vneshney politiki Rossiyskoy Federatsii v Tsentral'noy Azii v 1991-2012 gg. St. Petersburg: SPbGU Publ., 2014 (in Russian).

Mironov, B.N. Upravlenie etnicheskim mnogoobraziem Rossiiskoi imperii. St. Petersburg: Dmitry Bulanin Publ., 2017 (in Russian).

Naumkin, V.V. Interesy Rossii v Tsentral'noi Azii: soderzanie, perspektivy, ogranichiteli. Moscow: RAN Publ., 2013 (in Russian).

Paris, H. "La politique russe en Asie centrale." Géostrategiques, no. 28 (2010): 43-52 (in French).

Peyrouse, S. "La présence chinoise en Asie central: Portée géopolitique, engeux économique et impact culturelle." Les Etudes de CERI, no. 48 (2008): 29-31 (in French).

Peyrouse, S. "Quinze ans après l'indépendance, quels nouveaux enjeux en Asie Centrale?" Revue internationale et stratégique 64, no. 4 (2006): 65-68 (in French).

Poujol, C. "L'Asie centrale, bilan: quinze années de discours et de pratiques sur l'intégration dans un espace désintégré." Revue internationale et stratégique, no. 64 (2006): 69-78 (in French).

Pradon, H. "Les enjeux de sécurité et de la stabilité en Asie central." AFRI, no. 4 (2003): 161-176 (in French).

Reveillard, C. "La stratégie de la renaissance. Retour sur certaines évolutions de la situation géostratégique Russe." Géostratégiques, no. 24 (2016): 75-80 (in French).

Rousselot, H. "Le club de l'énergie de l'OSC. Un élément (moteur) d'intégration régionale?" Relations internationals, no. 145 (2011): 117-132 (in Russian).

Roy, O. L'Asie centrale contemporaine. Paris: Presses Universitaire de France, 2010 (in French).

Savichev, Iu.N. "Otnosheniia Rossii s tsentral'noaziatskimi stranami SNG v gumanitarnoi sfere (1991-2015)." Moscow: MSU Publ., 2015 (in Russian).

Sellier, A., and Sellier, J. Atlas des peuples d'Orient, Moyen-Orient, Caucase, Asie Centrale. Paris: La Découverte, 1993 (in French).

Teurtrie, D. "La langue russe. Un enjeu dans les relations entre la Russie et son étranger proche." Le Courrier des pays de l'Est, no. 1043 (2004): 67-75 (in French).

Teurtrie, D. Géopolitique de la Russie. Intégration régionale, enjeux énergétiques, influence culturelle. Paris: l'Harmattan, 2010 (in French).

Tinguy, de A. "La sortie de l'Empire: le poids de l'héritage." Questions internationals, no. 27 (2007): 6-21 (in French).

Trubnikova, N.V. Istoricheskie dviznenie 'Annalov. Tomsk: TSU Publ., 2007 (in Russian).

Tsykova, K.A. "Rossiia vtoroy poloviny XIX - nachala XX vv. v trudakh Anatolia Lerua-Bol'e.” Moscow: MSU Publ., 1991 (in Russian).

Verdier, A. "Les relations russo-centrasiatique. Une nouvelle donnée géopolitique, entre méfiance, velléité et intérêt." Les Cahiers de l'Orient, no. 89 (2008): 29-43 (in French).

Yakemtchouk, R. La politique étrangère de la Russie. Paris: l'Harmattan, 2008 (in French). 


\section{Библиографический список}

Абашин С.Н. Центральная Азия в составе Российской империи. М.: Новое литературное обозрение, 2008. $450 \mathrm{c}$.

Агеева В.В. Изучение России как империи: инновации в англо-американских историко-русских исследованиях в 1990-2010 годах // Теория и практика общественного развития. 2015. № 2. С. 65-78.

Арсланов Р.А., Климашин А.Л. Периодические издания России рубежа XIX-XX вв. о социокультурной адаптации русских переселенцев в Средней Азии // Вестник Российского университета дружбы народов. Серия: История России. 2017. № 3. С. 347-363.

Арсланов Р.А., Толстова Т.С. Взгляд со стороны: французские исследователи о современной России // Вестник Российского университета дружбы народов. Серия: История России. 2014. № 3. С. 155-162.

Бессмертный Ю.Л. Как же писать историю? Методические веяния во французской историографии 1994-1997 гг. // Новая и новейшая история. 1998. № 5. С. 29-42.

Брежнева С.Н. Историография проблемы присоединения Туркестанского края к России: вторая половина XIX - начало XX в. М.: МГУ, 2005. 320 с.

Брежнева С.Н. Отражение идеи аккультурации в переселенческой политике Российской империи в Туркестане на рубеже XIX - XX веков // Вестник Российского университета дружбы народов. Серия: История России. 2017. Т. 17. № 3. С. 608-638.

Гордон А.В. Россия в истории французской мысли (XVII-XXI вв.) // Россия и современный мир. 2013. № 4. С. 76-102.

Гуревич А.Я. Исторический синтез и школа «Анналов». М.: Индрик, 1993. 240 с.

Инергин А.М. Глобальная история Фернана Броделя: вопросы методологии. Томск: ТГУ, 1995. 210 с.

Казанцев А.A. «Большая игра» с неизвестными правилами: мировая политика и Центральная Азия. М.: МГИМО-Университет, 2008. 320 с.

Каррер д’Анкосс Э. Евразийская империя. М.: РОССПЭН, 2007. 360 с.

Китспоттер B. де. Большая игра в центральной Азии // Ядерный контроль. 2005. № 1. С. 81-102.

Костромина Н.Г. Теория и практика тоталитаризма в оценке французской исторической и политической мысли в ХХ в. Кемерово: КГУ, 2012. 310 с.

Лапина Н.Ю. Двойное зеркальное отражение, или Как современная Россия воспринимается во Франции // России и современный мир. 2013. № 4. С. 58-75.

Леклерк А. Русское влияние в Евразии. Геополитическая история от становления государства до времен Путина. М.: Альпина Паблишер, 2014. 365 с.

Лузианин С.Г. Восточная политика Владимира Путина. Возвращение России на «Большой Восток» (2004-2008). М.: АСТ, 2007. 435 с.

Мещеряков К.Е. Эволюция внешней политики Российской Федерации в Центральной Азии в 1991-2012 гг. СПб.: СПбГУ, 2014. 250 с.

Миронов Б.Н. Управление этническим многообразием Российской империи. СПб.: Дмитрий Буланин, 2017. $673 \mathrm{c}$.

Наумкин В.В. Интересы России в Центральной Азии: содержание, перспективы, ограничители. M.: PAH, 2013. $321 \mathrm{c}$.

Савичев Ю.Н. Отношение России с центральноазиатскими странами СНГ в гуманитарной сфере (1991 - 2015). М.: МГУ, 2015. $210 \mathrm{c}$.

Трубникова Н.В. Исторические движения «Анналов». Томск: ТГУ, 2007. 290 с.

Цуканова К.A. Россия второй половины XIX - начала XX вв. трудах Анатоля Леруа-Боле. М.: МГУ, 1991. $110 \mathrm{c}$.

Чудинов В.П. Французская историография распада СССР и становления современной России // Россия в мировом политическом процессе: материалы международной научно-теоретической конференции. М.: РУДН, 1997. С. 145-149.

Якцова Д.А. Власть и общественное движение в России XIX в. во французской историографии. М.: МГУ, 2013. $510 \mathrm{c}$.

Bernard V., Cvijic P., Fort L., Gangloff M., Moreau R. Russie: Quelle stratégie de puissance? // Base de Connaissance de AEGE. 2006. № 12. P. 28 - 35.

Cagnat $R$. Asie centrale, jouet des grandes puissences: le Très Grand Jeu // Les notes de l' IRIS. 2010. № 5. P. 45-53.

Carrère d'Encausse H. L'Empire éclaté. Paris: Flammarion, 1979. 314 p.

Carrère d'Encausse H. La Russie entre deux mondes. Paris: Fayard. 2010. 336 p.

Carrère d'Encausse H. Réformes et revolutions chez les musulmans de l'Empire russe. Bukhara 1867-1924.

Paris: Armand Colin, 1966. 311 p. 
Delcour $L$. Un nouvel aplomb sur la scène internationale? Comment la Russie voit-elle le monde? Éléments d'analyse d'une politique étrangère en mutation // Revue internationale et stratégique. 2007. № 68. P. 133-141.

Dreyfus F.-G. La Russie et l'Asie centrale // Géostratégiques. 2006. № 12. C. 99-106.

Djalili M.-R., Kellner T. La Russie et la «nouvelle» Asie central // Géostrategiques. 2001. № 1. P. 10-23.

Facon I. L'Asie centrale comme enjeu dans le partenariat stratégique sino-russe // Recherches et documents. Courrier des pays de l'Est. 2008. № 6. P. 23-32.

Facon I. Les enjeux de sécurité en Asie centrale: la politique de la Russie // AFRI. 2004. № 5. P. 653-666.

Facon I. L'organisation de coopération de Shanghai. Ambitions et intérêts russes // Le courrier des pays de l'Est. 2006. Vol. 1055. № 3. P. 26-37.

Gomart Th. Quelle influence russe dans l'espace post-soviétique? // Le courier des pays de l'Est. 2006. Vol. 1055. № 3. P. 4-13.

Kellner T., Djalili M.-R. Géopolitique de la nouvelle Asie Centrale. De la fin de l'URSS à l'après 11 septembre. Genève: Graduate Institute Publications, 2015. 457 p.

Laruelle M. La question des Russes de proche-étranger en Russie (1991-2006) // Les Etudes de CERI. 2006. № 126. P. 15-21.

Laruelle M. Le nouveaux role de la Russie en Asie Centrale: les migrations de travail des Centreasiatiques vers la Fédération russe // Revue internationale et stratégique. 2006. № 4. P. 133-142.

Mendras M. La Russie en mal de politique étrangère // Pouvoirs. 1999. № 88. P. 107-120.

Paris H. La politique russe en Asie centrale // Géostrategiques. 2010. № 28. P. 43-52.

Peyrouse S. Quinze ans après l'indépendance, quels nouveaux enjeux en Asie Centrale? // Revue internationale et stratégique. 2006. Vol. 64. № 4. P. 65-68.

Peyrouse $S$. La présence chinoise en Asie central: Portée géopolitique, engeux économique et impact culturelle // Les Etudes de CERI. 2008. № 48. P. 29-31.

Poujol C. L'Asie centrale, bilan: quinze années de discours et de pratiques sur l'intégration dans un espace désintégré // Revue internationale et stratégique. 2006. № 64. P. 69-78.

Pradon H. Les enjeux de sécurité et de la stabilité en Asie centrale // AFRI. 2003. № 4. P. 161-176.

Reveillard $C$. La stratégie de la renaissance. Retour sur certaines évolutions de la situation géostratégique Russe // Géostratégiques. 2016. № 24. P. 75-80.

Rousselot H. Le club de l'énergie de l'OSC. Un élément (moteur) d'intégration régionale? // Relations internationales. 2011. № 145. P. 117-132.

Roy O. L'Asie centrale contemporaine. Paris: Presses Universitaire de France. 2010. 128 p.

Sellier A., Sellier J. Atlas des peuples d'Orient, Moyen-Orient, Caucase, Asie Centrale. Paris: La Découverte, 1993. $194 \mathrm{p}$.

Teurtrie $D$. Géopolitique de la Russie. Intégration régionale, enjeux énergétiques, influence culturelle. Paris: l'Harmattan, 2010. 435 p.

Teurtrie D. La langue russe. Un enjeu dans les relations entre la Russie et son étranger proche // Le Courrier des pays de l'Est. 2004. № 1043. P. 67-75.

Tinguy de A. La sortie de l’Empire: le poids de l’héritage // Questions internationales. 2007. № 27. P. 6-21.

Verdier A. Les relations russo-centrasiatique. Une nouvelle donnée géopolitique, entre méfiance, velléité et intérêt // Les Cahiers de l’Orient. 2008. № 89. P. 29-43.

Yakemtchouk R. La politique étrangère de la Russie. Paris: l'Harmattan. 2008. 438 p.

\section{Информация об авторах / Information about the authors}

Арсланов Рафаэль Амирович, доктор исторических наук, профессор кафедры истории России Российского университета дружбы народов.

Трифонова Елизавета Дмитриевна, старший преподаватель кафедры иностранных языков Российского университета дружбы народов.
Rafael A. Arslanov, Doktor Istoricheskikh Nauk [Dr. habil. hist.], Professor of the Department of Russian History, RUDN University.

Elizaveta D. Trifonova, Senior Lecturer, Department of Foreign Languages, RUDN University. 